\title{
A perspective for rural development based on the dairy-farming production system in Iporá and surroundings, Goiás State
}

\section{Uma perspectiva de desenvolvimento rural baseada no sistema de produção de leite em Iporá e adjacências, Estado de Goiás}

\author{
Kaique M. Dias ${ }^{1}$, Marisa M. Silva ${ }^{1}$, Alcido E. Wander ${ }^{2}$, Paulo A. P. Salviano ${ }^{3}$,Eduardo R. de Carvalho $*^{4}$
}

\begin{abstract}
Iporá and adjacent municipalities. In the present work 257 interviews were conducted from April to November 2013 in several locations. Mean milk production per farm was 207.9 liters/day and dairy cow yield was 7.8 liters/day. The indicators of pasture degradation was high $(n=111 / 63.8 \%)$. Natural breeding was more frequent $(n=155 / 82.4 \%)$ than artificial insemination $(n=33 / 17.6 \%)$. Milking cows manually was more frequent $(n=146 / 82.9 \%)$ than mechanical milking $(n=30 / 17.1 \%)$. The most predominant milking construction was the roofless shed with packed earth floor $(n=98 / 63.2 \%)$. Milk quality may be reduced due to certain procedures adopted during milking (48 herdsmen dry the saliva of the calf on the teat surface with the cow tail, 63 herdsmen remove the saliva of the calf on the teat surface by hand and dry it on the cow coat, and 67 herdsmen remove the saliva of the calf on the teat surface by hand and dry it on their pants). Vaccination against leptospirosis, bovine viral diarrhea, infectious bovine rhinotracheitis and neosporosis was low ( $\mathrm{n}=26,24,20$ and 7, respectively). The dairy-farming production system in Iporá and surroundings needs improvements to increase milk production and create opportunities for rural development.
\end{abstract}

Key words: cow, efficiency, milk, productivity, specialization

Resumo: objetivou-se nesse estudo caracterizar o sistema de produção de leite em Iporá e municípios adjacentes. Realizaramse 257 entrevistas entre abril e novembro de 2013 em diversos locais. A produção de leite por fazenda foi de 207,9 litros/dia e a produtividade/vaca foi de 7,8 litros/dia. Os indicadores de degradação de pastagens foram altos $(\mathrm{n}=111 / 63,8 \%)$. A monta natural foi mais frequente $(n=155 / 82,4 \%)$ que a inseminação artificial $(n=33 / 17,6 \%)$. A ordenha manual foi mais frequente $(n=146 / 82,9 \%)$ que a mecânica $(n=30 / 17,1 \%)$. O tipo de construção predominante foi o barracão descoberto com piso de chão batido ( $\mathrm{n}=98 / 63,2 \%)$. A qualidade do leite pode ser reduzida devido a certos procedimentos adotados durante a ordenha (48 ordenhadores secam a saliva do bezerro na superfície do teto com o rabo da vaca, 63 ordenhadores removem a saliva do bezerro na superfície do teto com a mão e a seca no pelo da vaca, e 67 ordenhadores removem a saliva do bezerro na superfície do teto com a mão e a seca na calça). A vacinação contra leptospirose, diarreia viral bovina, rinotraqueíte infecciosa bovina e neosporose foi baixa $(n=26,24,20$ e 7, respectivamente). O sistema de produção em Iporá e municípios adjacentes necessita de melhorias para aumento na produção de leite e oportunidades de desenvolvimento rural.

Palavras-chaves: eficiência, especialização, leite, vaca, produtividade

\footnotetext{
*Autor para correspondência

Recebido para publicação em 20/06/2015; aprovado em 10/07/2015

${ }^{1}$ Discentes do Curso Superior de Tecnologia em Agronegócio, IF Goiano (Câmpus Iporá/GO), kaique18dias@ gmail.com, mmarsilva01@ gmail.com

${ }^{2}$ Doutor em Economia Agrícola, Embrapa Arroz e Feijão, Rodovia GO 462, km 12, zona rural, Santo Antônio de Goiás/GO, alcido.wander@embrapa.br

${ }^{3}$ Mestre em Desenvolvimento Regional, IF Goiano (Câmpus Iporá), Avenida Oeste, nº 350, Parque União, Iporá/GO, paulo.salviano@ifgoiano.edu.br

${ }^{4}$ Doutor em Ciência Animal, IF Goiano (Câmpus Iporá), Avenida Oeste, nº 350, Parque União, Iporá/GO, eduardo.carvalho@ifgoiano.edu.br
} 


\section{INTRODUCTION}

A dairy production system can be assessed by the zootechnical indexes that are correlated with the dairy farm performance and the profitability of the activity. Dairy farmers should be careful when calculating the zootechnical indexes to identify the ones that present the biggest deviation in regard to a desirable dairy production system (LOPES et al., 2009). Once dairy producers do not have an influence on milk price, there should be better administration and management of the variables that are under the farmer's control and indeed have a great impact on the dairy production system and the profitability of the activity (LOPES et al., 2012). Therefore it is essential to describe and characterize a dairy production system from a particular region, which will help farmers to adopt the adequate existing technologies and consequently increase milk production (CHINELATTO NETO et al., 2005).

The economy of Iporá and adjacent municipalities (Amorinópolis, Diorama, Israelândia, Ivolândia e Jaupaci) has been primarily based on dairy farming and, in a lower scale, on beef cattle raising. From a total of 421,000 heads of cattle existing in these six municipalities, 49,800 dairy cows have been milked daily with a production of 154,923 liters of milk (IBGE, 2013). Nevertheless, the data reported by IBGE (2013) are insufficient to accurately characterize the dairyfarming production system in Iporá and surroundings. From this perspective, the survey and the collection of these data are essential to describe more precisely the dairy production system of this region, which requires a structured and detailed methodology that can assess each individual variable aiming to interpret and analyze all information collected as a systemic and holistic model (PORTELA et al., 2002).

The objective of the present study was to characterize the dairy-farming production system in Iporá and surroundings, and indicate alternatives that may fit in the dairy production system of this region with potential to increase milk production and create new perspectives for rural development.

\section{MATERIALS AND METHODS}

In the present study 257 interviews with farmers from Iporá and surrounding municipalities (Amorinópolis, Diorama, Israelândia, Ivolândia and Jaupaci) in Goiás State were conducted from April to November 2013. The interviews were carried out by eight students and two faculty members of the Agribusiness Course of the Goiano Federal Institute (IF Goiano, Iporá Campus). The interviews happened in several locations and opportunities, such as in a field day organized by PROCRIA Health and Animal Nutrition, in a joint effort of a family-farming cooperative (COOMAFIR), in meetings of rural communities, in a local association of family-based farmers (APROSANTA), in an agriculture and livestock retailer store from Iporá (PROCRIA), in the office of the Agricultural and Livestock Defense Agency of Goiás State (AGRODEFESA) during the campaign of vaccination against the foot and mouth disease in May and November, and during the $28^{\text {th }}$ Agricultural Exhibition of Iporá. Farmers were randomly approached for the interviews and the data were collected without identification of the respondents (farmers). Protocols were approved by the Ethics Research Committee of the Goiano Federal Institute (decision \# 4/2014).

The questionnaire was divided in sections about family composition, socioeconomic and environmental aspects, infrastructure of the farm, main sources of farm income, production system of beef cattle raising and dairy-farming, annual crops cultivation, fruit growing, and vegetable production. The dairy-farming section of the questionnaire contained closed and open questions about milk production, dairy cow performance, indicators of pasture degradation and methods of pasture renovation, breeding methods, milking system, milking routine, and vaccine administration.

The data were analyzed using the Statistical Package for Social Sciences (SPSS) version 21.0 (IBM CORP., 2012). Data were entered as quantitative (scale) or qualitative (nominal) variables. Values reported are frequencies, percentages, means and associated standard errors. When appropriate, values are reported in cross tables for a better understanding of the data (Tables 1, 3, and 7).

\section{RESULTS AND DISCUSSION}

The data of farm and dairy cow performance are presented in Table 1. From a total of 177 dairy farms, 112 $(63.3 \%)$ have a daily milk production of up to 150 liters. The mean number of lactating cows/farm is $26 \pm 27$ producing 207.9 liters/day, which corresponds to a cow performance of 7.8 liters/day. The data reported in Table 1 are below the mean of Goiás State evaluated from August 2000 to July 2001. At that time, the milk production/farm was 552 liters/day and the dairy cow productivity was 9.86 liters/day (LOPES et al., 2007). Thus, the data reported in Table 1 infer that the dairy-farming production system in Iporá and surroundings indicates low yields and may affect the profitability of the dairy activity. In addition, the high number of dry cows $(29 \pm 53)$ compared with the number of lactating cows $(26 \pm 27)$ also contributes to reduce dairy-farming performance and has a great impact on the cost of milk produced due to increased feeding costs with cows that are not in lactation (LOPES et al., 2009).

The dairy cow performance reported by IBGE (2013) in Iporá and surroundings was 3.1 liters/day (considering 49,800 cows milked daily with a production of 154,923 liters). This productivity is extremely low and in disagreement with the data reported in the present study as well as by Lopes et al. (2007). This discrepancy may happen due to inaccuracy during the collection of data reported by IBGE (2013), although it represents the official data from the Brazilian Government.

A high number of dairy farmers $(n=111 / 63.8 \%)$ reported indicators of pasture degradation (Table 2), such as reduction of pasture yield, patches of bare soil, weed invasion, and appearance of termite mounds. Accordingly, a high number of dairy farmers have renovated pastures $(n=130 / 75.1 \%)$ as an attempt to reverse pasture degradation.

The most frequently reported methods of pasture renovation were tilling, fertilization and seed broadcasting $(n=33 / 28.9 \%)$; tilling and seed broadcasting $(n=33 / 28.9 \%)$; and tilling, soil correction with limestone or phosphate fertilizer or both, and seed broadcasting ( $n=19 / 16.7 \%)$. However, just five dairy farmers $(4.4 \%)$ have opted for croplivestock integration as a method of pasture renovation. 
Table 1 - Milk production of dairy farms in Iporá and surroundings (Goiás State)

\begin{tabular}{|c|c|c|c|c|}
\hline Milk (liters/day) ${ }^{1}$ & Frequency $(\mathrm{n})$ & Lactating cows (n) & Dry cows $(n)$ & Lactation length (days) \\
\hline Up to 50 & 45 & & & \\
\hline $51-100$ & 31 & & & \\
\hline $101-150$ & 36 & & & \\
\hline $151-200$ & 17 & $26 \pm 27$ & $29 \pm 53$ & $242 \pm 45$ \\
\hline $201-300$ & 23 & & & \\
\hline $301-600$ & 17 & & & \\
\hline $601-2,000$ & 8 & & & \\
\hline Total $^{2}$ & 177 & 177 & 171 & 174 \\
\hline
\end{tabular}

${ }^{1}$ Mean of 207.9 liters/farm/day and 7.8 liters/cow/day

${ }^{2}$ Total of farmers who replied to this variable

Crop-livestock integration systems have been reported to reverse pasture degradation with increased crop, pasture, and livestock yields (CARVALHO et al., 2010). The benefits of crop-livestock integration systems include increased soil fertility due to greater accumulation of organic matter, improved nutrient cycling, increased fertilizer efficiency, and better soil aggregation (SALTON et al., 2014). Rotation of crops with livestock can also help to control crop disease and weed invasion, thus reducing production costs and increasing environmental outcomes through less use of agrochemicals (MARTHA JUNIOR et al., 2011).

Hence, according to the benefits above-described, dairy farmers in Iporá and surroundings should begin to experience crop-livestock integration as a method of pasture renovation in order to improve the dairy-farming production system.

The great majority of farmers $(n=155 / 82.4 \%)$ have opted for natural breeding as opposed to artificial insemination $(n=33 / 17.6 \%)$ as a breeding method (Table 3). Furthermore, 97 farmers $(62.6 \%)$ with a daily milk production of up to 150 liters have utilized natural breeding, whereas only 19 farmers $(57.6 \%)$ with a daily milk production from 201 to 2,000 liters have used artificial insemination. Therefore, the data presented in Table 3 indicate that small dairy farmers have used natural breeding while bigger dairy farmers have opted for the artificial insemination method.

In the natural breeding system it is not uncommon that two or more bulls cross with dairy cows and heifers. One of the problems associated with this system is the unknown paternity of the calves if two or more bulls are together with cows or heifers, as well as the reduction in the total number of cows due to the necessity of having bulls on the farm, which will ultimately decrease the potential of milk production. On the other hand, artificial insemination provides for several benefits, such as genetic improvement of the dairy herd due to the introduction of sires with greater milk performance and high heritability for characteristics related with milk production and mammary gland health, reduction on the number of bulls on the farm which will be utilized only in cases when cows and heifers have not been successfully bred by artificial insemination, greater control of the reproductive data of the dairy herd, and early detection of reproductive failures. However, highly-qualified labor for heat detection and artificial insemination procedures, as well as adequate feeding and nutritional management of dairy cows and heifers are necessary to obtain high fertility rates with the artificial insemination method (NEVES et al., 2010).

Table 2 - Indicators of pasture degradation, frequency of pasture renovation, and methods of pasture renovation in Iporá and surroundings (Goiás State)

\begin{tabular}{|c|c|c|}
\hline Indicators of pasture degradation & Frequency (n) & Percentage (n) \\
\hline Yes & 111 & 63.8 \\
\hline No & 63 & 36.2 \\
\hline Total $^{1}$ & 174 & 100 \\
\hline Pasture renovation & Frequency (n) & Percentage $(\mathrm{n})$ \\
\hline Yes & 130 & 75.1 \\
\hline No & 43 & 24.9 \\
\hline Total $^{1}$ & 173 & 100 \\
\hline Methods of pasture renovation & Frequency $(\mathrm{n})$ & Percentage $(\mathrm{n})$ \\
\hline Tilling, fertilization and seed broadcasting & 33 & 28.9 \\
\hline Tilling and seed broadcasting & 33 & 28.9 \\
\hline Tilling, soil correction, fertilization and seed broadcasting & 19 & 16.7 \\
\hline Tilling, soil correction and seed broadcasting & 13 & 11.4 \\
\hline Tilling and letting the pasture regrow & 5 & 4.4 \\
\hline Crop-livestock integration & 5 & 4.4 \\
\hline Only seed broadcasting & 3 & 2.6 \\
\hline According to the Agronomist's recommendation & 2 & 1.8 \\
\hline Seed broadcasting and fertilization & 1 & 0.9 \\
\hline Total $^{1}$ & 114 & 100 \\
\hline
\end{tabular}

\footnotetext{
${ }^{1}$ Total of farmers who replied to this variable
} 
Table 3 - Breeding methods and milk production of dairy farms in Iporá and surroundings (Goiás State) according to the breeding method utilized

\begin{tabular}{lcc}
\hline Breeding method & Frequency $(\mathrm{n})$ & Percentage $(\%)$ \\
\hline Natural breeding & 155 & 82.4 \\
Artificial insemination & 33 & 17.6 \\
Total $^{1}$ & 188 & 100 \\
\hline Milk (liters/day) $^{\text {Up to } 50}$ & Natural breeding (n) & Artificial insemination (n) \\
$51-100$ & 34 & 3 \\
$101-150$ & 29 & 3 \\
$151-200$ & 34 & 4 \\
$201-300$ & 16 & 5 \\
$301-600$ & 22 & 9 \\
$601-2,000$ & 15 & 5 \\
Total $^{1}$ & 5 & 33 \\
\hline
\end{tabular}

${ }^{1}$ Total of farmers who replied to this variable

Furthermore, slightly more than half of the farmers ( $n=42 / 51.2 \%$; Table 4) have chosen dairy bull breeds (Holstein, Girolando, Dairy Gir, Jersey and Brown Swiss) either in natural breeding or artificial insemination, whereas a little less than half ( $n=40 / 48.8 \%$; Table 4$)$ of the farmers have used beef bull breeds (Nelore, Tabapuã, undefined crossbreeding, Simental and Caracu). The choice of a beef bull breed instead of a dairy bull breed can be considered a reproductive strategy that does not contribute to increase milk production and is an indication of a low level of dairyfarming specialization, which has been previously reported to be essential to improve the production system and increase milk production (LEMOS et al., 2003).

The destination of dairy bull calves is reported in Table 5. Most of dairy bull calves $(n=150 / 85.2 \%)$ have been sold just after they are weaned. Taking into account that a great number of farmers $(n=155 / 82.4 \%)$ have chosen natural breeding as a reproductive method (Table 3), the likelihood of either a heifer or a bull calf to be born is $50 \%$ each, therefore raising and finishing dairy bull calves for beef may be an attractive alternative to increase farm income and contribute for the improvement of the dairy production system. However, good planning and remodeling of the farm for additional forage production both fresh (during the rainy season) and preserved as either silage or hay during the dry season is necessary in order to raise these animals with satisfactory weight gain.
Although overall resources and care with bull calves is much less than with heifer calves on a dairy farm, raising dairy bull calves for veal production has been well consolidated in countries where dairy farming is advanced and developed, such as Holland, France, Italy, the United States and Canada (CARVALHO et al., 2003).

In addition, recent studies reported that dairy bull calves grazing on Brachiaria brizantha and fed a high (1\% body weight) or medium ( $0.5 \%$ body weight) level of energy supplement (cracked corn plus minerals) gained 0.88 and 0.62 $\mathrm{kg} /$ day on a 126-day experiment for the high and medium level of supplementation, respectively (REZENDE et al., 2011). The same animals were further divided in two groups on a feedlot experiment and fed diets with 50:50 or 20:80 forage/concentrate ratio. The expected slaughter weight of $395 \mathrm{~kg}$ was obtained after 84, 105, 126 and 126 days on feedlot for the high level of supplementation during raising and 20:80 forage/concentrate ratio during finishing, high level of supplementation during raising and 50:50 forage/concentrate ratio during finishing, medium level of supplementation during raising and 20:80 forage/concentrate ratio during finishing, and medium level of supplementation during raising and 20:80 forage/concentrate ratio during finishing, respectively (REZENDE et al., 2012). Collectively, the data reported by Rezende et al. (2011) and Rezende et al. (2012) suggest that raising and finishing dairy bull calves may be technically and biologically efficient depending upon feeding strategies during the raising and finishing phases.

Table 4 - Bull breeds utilized in dairy farms from Iporá and surroundings (Goiás State) either in natural breeding or artificial insemination

\begin{tabular}{lcc}
\hline Bull breed & Frequency $(\mathrm{n})$ & Percentage $(\%)$ \\
\hline Holstein & 25 & 30.5 \\
Girolando (Dairy Gir × Holstein) & 11 & 13.4 \\
Dairy Gir & 3 & 3.7 \\
Jersey & 2 & 2.4 \\
Brown Swiss & 1 & 1.2 \\
Nelore & 29 & 35.4 \\
Tabapuã & 5 & 6.1 \\
Undefined cross-breeding & 3 & 3.7 \\
Simental & 2 & 2.4 \\
Caracu & 1 & 1.2 \\
Total & 82 & 100 \\
\hline
\end{tabular}

${ }^{1}$ Total of farmers who replied to this variable 
Table 5 - Destination of dairy bull calves in dairy farms from Iporá and surroundings (Goiás State)

\begin{tabular}{lcc}
\hline Destination & Frequency (n) & Percentage (\%) \\
\hline Sale at weaning & 150 & 85.2 \\
Raising and finishing on the farm & 14 & 8.0 \\
Raising and selling to another farmer for finishing & 12 & 6.8 \\
Total $^{1}$ & 176 & 100 \\
\hline
\end{tabular}

${ }^{1}$ Total of farmers who replied to this variable

Out of a total of 176 dairy farmers who replied to this variable, $146(82.9 \%)$ have milked cows manually $(n=115 /$ $65.3 \%$ once a day and $n=31 / 17.6 \%$ twice a day), whereas only 30 dairy farmers $(17.1 \%)$ have utilized a mechanical milking system (Table 6). Moreover, the roofless shed with packed earth floor was the most predominant $(n=98 / 63.2 \%)$ facility (Table 6). The data presented in Table 6 suggest that the milking system and milking facilities in dairy farms from Iporá and surroundings have not followed the ongoing innovation and technologies of the dairy industry (BOTEGA et al., 2008; MILANI e SOUZA, 2010). In addition, the primary goal of a farming construction is to provide adequate conditions for animal welfare in order to maximize animal performance (COSTA et al., 2013), which may not be the case in roofless sheds with packed earth floor when the excessive accumulation of mud during the rainy season may favor environmental mastitis and a consequent reduction in milk production and milk quality.

Smaller farmers with a daily milk production of up to 150 liters have milked cows manually either once $(n=87 / 75.6 \%)$ or twice $(n=21 / 67.7 \%)$ a day (Table 7$)$, as opposed to bigger dairy farmers with a daily milk production of 201 to 2,000 liters who have milked cows using a bucket milking either once $(n=2 / 50 \%)$ or twice $(n=12 / 75 \%)$ a day, or a milking parlor twice a day $(n=10 / 100 \%)$. Likewise with the data reported in Table 3, the data presented in Table 7 infer that the choice of either a manual or a mechanical milking system is related with the scale of milk production.

A great number of dairy farmers have adopted certain procedures during milking which make the entire operation more time consuming and less efficient (Table 8), such as allowing calves to suck from their mothers prior to milking $(n=143)$, tying up cow legs $(n=148)$, tying up calves on the right hand of the cow $(n=139)$, and allowing calves to suck the remaining milk of the cow after milking $(n=141)$. Together, these procedures increase the time spent with milking resulting in less time available for other activities (e.g. feeding, pasture management, silage production, heat detection, fencing, and general maintenance, among others), which could result in improvements of the dairy production system.

Table 6 - Milking system, milking frequency, and milking facilities in dairy farms from Iporá and surroundings (Goiás State)

\begin{tabular}{lcc}
\hline Milking system and milking frequency & Frequency $(\mathrm{n})$ & Percentage $(\%)$ \\
\hline Manual milking once a day & 115 & 65.3 \\
Manual milking twice a day & 31 & 17.6 \\
Bucket milking once a day & 4 & 2.3 \\
Bucket milking twice a day & 16 & 9.1 \\
Milking parlor twice a day & 10 & 5.7 \\
Total $^{1}$ & 176 & 100 \\
\hline Milking facilities $^{\text {Roofless shed with packed earth floor }}$ & 98 & 63.2 \\
Roofed shed with cemented floor & 19 & 12.3 \\
Roofed shed with packed earth floor & 36 & 23.2 \\
Roofless shed with cemented floor & 2 & 1.3 \\
Total & & 100 \\
\hline
\end{tabular}

${ }^{1}$ Total of farmers who replied to this variable

Table 7 - Performance of dairy farms from Iporá and surroundings (Goiás State) according to the milking system utilized

\begin{tabular}{lccccc}
\hline \multirow{2}{*}{ Milk (liters/day) } & \multicolumn{5}{c}{ Frequency (n) } \\
\cline { 2 - 6 } & $\begin{array}{c}\text { Manual milking } \\
\text { once a day }\end{array}$ & $\begin{array}{c}\text { Manual milking } \\
\text { twice a day }\end{array}$ & $\begin{array}{c}\text { Bucket milking } \\
\text { once a day }\end{array}$ & $\begin{array}{c}\text { Bucket milking } \\
\text { twice a day }\end{array}$ & $\begin{array}{c}\text { Milking parlor } \\
\text { twice a day }\end{array}$ \\
\hline Up to 50 & 39 & 5 & 0 & 1 & 0 \\
$51-100$ & 24 & 7 & 0 & 0 & 0 \\
$101-150$ & 24 & 9 & 1 & 1 & 0 \\
$151-200$ & 8 & 6 & 1 & 2 & 0 \\
$201-300$ & 10 & 2 & 1 & 4 & 2 \\
$301-600$ & 8 & 2 & 1 & 0 & 3 \\
$601-2,000$ & 2 & 0 & 4 & 16 & 5 \\
Total & 115 & 31 & & 0 \\
\hline
\end{tabular}

Still in Table 8, only 24 dairy farmers have adopted milking procedures that prevent mastitis and/or environmental milk contamination (21 farmers start milking with the strip cup test, pre-dipping solution application, teat drying, teat cup attachment, teat cup removal, and post-dipping solution application, while three farmers start milking with the predipping solution application, teat drying, strip cup test, teat cup attachment, teat cup removal, and post-dipping solution application). Contrarily, certain procedures have been adopted which may increase the risk for mastitis incidence and/or 
environmental milk contamination (48 herdsmen dry the remaining saliva of the calf on the teat surface with the cow tail, 63 herdsmen remove the remaining saliva of the calf on the teat surface by hand and dry it on the cow coat, and 67 herdsmen remove the remaining saliva of the calf on the teat surface by hand and dry it on their pants).

After milk has been synthetized in the cow's mammary gland it can be contaminated by microorganisms in two different ways: inside the mammary gland, as a result of mastitis incidence, and shortly after milking by bacteria found on the teat, the udder and the equipment surface (GUERREIRO et al., 2005). Therefore, health of the mammary gland, adequate environmental conditions where cows are housed during milking, and suitable cleaning and sanitization of milking equipment are key factors to minimize bacterial raw milk contamination.

The pre-dipping solution application prevents the contamination of milking equipment by environmental microorganisms found on the teat surface and cow-to-cow cross-contamination during milking. The post-dipping solution application avoids the incidence of mastitis shortly after milking while the teat orifice is still open for 20 to 30 minutes (YAMAMURA et al., 2008).

Slightly more than half of the dairy farms $(n=88 / 50.6 \%)$ have a cooling tank for milk storage (Table 8). Cooling milk temperature to $4^{\circ} \mathrm{C}$ within two hours after milking is relevant to the reduction of bacterial growth and maintains the raw milk quality until it reaches the dairy industry (FAGUNDES et al., 2006).

Although the data reported in Tables 6 and 8 indicate that the milk quality may not be high owing to poor infrastructure and milking procedures that favor bacterial contamination, farmers should first maximize resources for improving the dairy production system with increasing milk production to create possibilities for investments in new constructions and modern milking equipment.

Table 8 - Milking routine in dairy farms from Iporá and surroundings (Goiás State)

\begin{tabular}{|c|c|c|c|}
\hline Milking procedures & Yes & No & Total $^{1}$ \\
\hline Calves are kept with their mothers from early milking until noon & 131 & 30 & 161 \\
\hline Calves are allowed to suck from their mothers prior to milking & 143 & 17 & 160 \\
\hline Cow legs are tied up with a rope & 148 & 09 & 157 \\
\hline Calves are tied up on the right hand of the cow & 139 & 18 & 157 \\
\hline $\begin{array}{l}\text { The herdsman dries the remaining saliva of the calf on the teat surface with the } \\
\text { cow tail }\end{array}$ & 48 & 109 & 157 \\
\hline $\begin{array}{l}\text { The herdsman removes the remaining saliva of the calf on the teat surface by } \\
\text { hand and dries it on the cow coat }\end{array}$ & 63 & 94 & 157 \\
\hline $\begin{array}{l}\text { The herdsman removes the remaining saliva of the calf on the teat surface by } \\
\text { hand and dries it on his pants }\end{array}$ & 67 & 89 & 156 \\
\hline The herdsman lets the calf suck the remaining milk of the cow & 141 & 16 & 157 \\
\hline $\begin{array}{l}\text { Strip cup test, pre-dipping solution application, teat drying, teat cup attachment, } \\
\text { teat cup removal, and post-dipping solution application }\end{array}$ & 21 & 139 & 160 \\
\hline $\begin{array}{l}\text { Pre-dipping solution application, teat drying, strip cup test, teat cup attachment, } \\
\text { teat cup removal, and post-dipping solution application }\end{array}$ & 3 & 157 & 160 \\
\hline The farm has a cooling tank for milk storage & 88 & 86 & 174 \\
\hline
\end{tabular}

${ }^{1}$ Total of farmers who replied to this variable

The majority of the farmers have vaccinated their animals against foot and mouth disease $(n=176)$, bovine rabies $(n=174)$ and brucellosis $(n=172)$ (Table 9). These vaccines are compulsory according to the AGRODEFESA regulations. In addition to the three diseases abovementioned, the number of dairy farmers who have vaccinated animals against blackleg is also high $(n=162)$. Contrarily, the frequency of vaccination against leptospirosis, bovine viral diarrhea (BVD), infectious bovine rhinotracheitis (IBR) and neosporosis was low $(\mathrm{n}=26, \mathrm{n}=24, \mathrm{n}=20$ and $\mathrm{n}=7$, respectively). Consequently, the animals may be constantly vulnerable to these diseases in cases of possible contact with the pathogenic agent.

Leptospirosis is a zoonotic disease that is responsible for economic losses in dairy farms due to abortions, retained placenta, premature births, stillborn calves, cow infertility and reduction in milk production (ELLIS, 1984). Dairy cows nearby the capital of Goiás State (Goiânia) had $81.9 \%$ $(n=349 / 426)$ of prevalence of animals that tested positive for leptospirosis (JULIANO et al., 2000). The same authors reported that nine cows aborted out of 349 positively infected.

Losses caused by BVD are a result of infection of pregnant cows causing abortion, stillborn calves, fetal malformation, and calves that are born weak and persistently infected. Studies in non-vaccinated dairy cows detected $65.66 \%$ of BVD infection (CHAVES et al., 2012).

Similarly to BVD, IBR causes reduction in performance and abortion. Out of 5,511 blood serum samples tested in Minas Gerais State between 1990 and 1999, 3,206 (58.2\%) contained antibodies against the IBR virus (ROCHA et al., 2001).

Neosporosis is also a disease that causes abortion, infertility and stillborn calves. Earlier research reported that the level of infection of neosporosis in culled crossbred dairy cows and fetuses from pregnant culled cows was $97.2 \%$ $(n=559 / 575)$ and $12.7 \%(n=64 / 503)$, respectively, both in blood serum samples collected in a slaughter house in the south of Minas Gerais State (GUEDES et al., 2008).

Together, the data reported by Juliano et al. (2000), Rocha et al. (2001), Guedes et al. (2008) and Chaves et al. (2012) indicate that vaccination against leptospirosis, BVD, IBR and neosporosis is essential to prevent economic losses caused by such diseases, especially disruptions in the cow's reproductive system, which will inevitably have an impact on milk production. 
Table 9 - Vaccination in dairy farms from Iporá and surroundings (Goiás State)

\begin{tabular}{lccc}
\hline Disease & Yes & No & Total $^{1}$ \\
\hline Foot and mouth & 176 & 0 & 176 \\
Bovine rabies & 174 & 2 & 176 \\
Brucellosis & 172 & 3 & 175 \\
Blackleg & 162 & 12 & 174 \\
Leptospirosis & 26 & 142 & 168 \\
Bovine viral diarrhea (BVD) & 24 & 143 & 167 \\
Infectious bovine rhinotracheitis (IBR) & 20 & 147 & 167 \\
Neosporosis & 7 & 160 & 167 \\
\hline
\end{tabular}

${ }^{1}$ Total of farmers who replied to this variable

Pearson correlation coefficients among quantitative characteristics for milk production are presented in Table 10. Milk production (MP) was significantly $(\mathrm{P}<0.01)$ correlated with number of lactating cows (LC, $\mathrm{r}=0.68$ ), number of dry cows (DC, $r=0.31$ ), number of culled cows in the last twelve months $(\mathrm{CC}, \mathrm{r}=0.28)$, number of heifer calves from one day to six months of age $(\mathrm{HC} 1, \mathrm{r}=0.42)$, number of heifer calves from six to twelve months of age $(\mathrm{HC} 2, \mathrm{r}=0.25)$, number of heifers raised on the farm for replacement in the last twelve months (HR, r=0.39), farm size (FS, $r=0.27$ ), area of the farm with pasture (AP, $\mathrm{r}=0.25$ ), amount of concentrate fed daily to lactating cows (CLC, $\mathrm{r}=0.27$ ), number of calves born in the last twelve months $(\mathrm{CB}, \mathrm{r}=0.37)$ and number of calves that died in the last twelve months $(\mathrm{CD}, \mathrm{r}=0.26)$. The variables that were not significantly $(\mathrm{P}>0.05)$ correlated with milk production were lactation length ( $\mathrm{LL}, \mathrm{r}=0.14)$, area of the farm designated for silage production (AS, $\mathrm{r}=0.25)$, and area of the farm planted with sugar-cane (ASC, $r=0.19$ ),

Moreover, the coefficient of determination $\left(\mathrm{R}^{2}\right)$ in the linear regression analysis was high (0.99). The model accounted for the effects of number of lactating cows, area of the farm with pasture, area of the farm designated for silage production, area of the farm planted with sugar-cane, amount of concentrate fed daily to lactating cows, and lactation length as independent variables. When a second linear regression analysis was run considering only the effect of number of lactating cows as an independent variable the $\mathrm{R}^{2}$ was lower (0.46). In both linear regression analyses the daily milk production was the dependent variable.

The data reported in Table 10 and the $\mathrm{R}^{2}$ of the first linear regression analysis suggest that the variables previously mentioned (except lactation length, area of the farm designated for silage production, and area of the farm planted with sugar-cane) are relevant to increase milk production.

Therefore dairy farmers should spend the same proportion of resources (knowledge, labor, investments, management, infrastructure, etc.) on these variables in order to improve the dairy-farming production system and increase milk yield. For instance, a good care of a heifer calf since its first day of life means that it will be bred earlier and will become a healthy and productive dairy cow to replace another cow that needs to be voluntarily culled for various reasons (e.g. mastitis, advanced age, laminitis, infertility, etc.). Besides, well-managed pastures will result in a higher high dry matter yield and nutritive value of the forage, and consequently will help to meet the nutrient demand of dairy animals. Thus, farmers should visualize the dairy-production system as different units of the farm that fit together and work as a synchronized model, which will ultimately result in a productive and profitable lactating cow.

Table 10 - Pearson correlation coefficients among quantitative characteristics for milk production in dairy farms from Iporá and surroundings (Goiás State)

\begin{tabular}{|c|c|c|c|c|c|c|c|c|c|c|c|c|c|c|}
\hline Variable & $\mathrm{LC}$ & $\mathrm{DC}$ & $\mathrm{CC}$ & $\mathrm{HC} 1$ & $\mathrm{HC} 2$ & $\mathrm{HR}$ & LL & $\mathrm{FS}$ & AP & $\mathrm{AS}$ & ASC & CLC & $\mathrm{CB}$ & $\mathrm{CD}$ \\
\hline $\mathrm{MP}$ & $0.68 * *$ & $0.31 * *$ & $0.28 * *$ & $0.42 * *$ & $0.25 * *$ & $0.39 * *$ & 0.14 & $0.27 * *$ & $0.25 * *$ & 0.25 & 0.19 & $0.27 * *$ & $0.37 * *$ & $0.26 * *$ \\
\hline $\mathrm{LC}$ & & $0.42 * *$ & $0.62 * *$ & $0.77 * *$ & $0.55^{* *}$ & $0.64 * *$ & 0.08 & $0.52 * *$ & $0.53 * *$ & $0.41 * *$ & $0.42 * *$ & 0.05 & $0.70 * *$ & $0.35 * *$ \\
\hline DC & & & $0.33^{* *}$ & $0.39 * *$ & $0.19^{*}$ & $0.70^{* *}$ & -0.08 & $0.48^{* *}$ & $0.54 * *$ & $0.56^{* *}$ & $0.43 * *$ & -0.05 & $0.33^{* *}$ & $0.19^{*}$ \\
\hline $\mathrm{CC}$ & & & & $0.71 * *$ & $0.72 * *$ & $0.31 * *$ & -0.01 & $0.36 * *$ & $0.44 * *$ & $0.58 * *$ & $0.33^{*}$ & 0.02 & $0.71 * *$ & $0.18^{*}$ \\
\hline $\mathrm{HC} 1$ & & & & & $0.65^{* *}$ & $0.61 * *$ & 0.04 & $0.49 * *$ & $0.53 * *$ & $0.44 * *$ & $0.41 * *$ & 0.04 & $0.79 * *$ & $0.24 * *$ \\
\hline $\mathrm{HC} 2$ & & & & & & $0.50 * *$ & $0.20^{*}$ & $0.27 * *$ & $0.36^{* *}$ & 0.30 & $0.46^{* *}$ & 0.11 & $0.92 * *$ & 0.15 \\
\hline HR & & & & & & & -0.05 & $0.50 * *$ & $0.54 * *$ & $0.65^{* *}$ & 0.11 & -0.03 & $0.72 * *$ & 0.18 \\
\hline LL & & & & & & & & -0.13 & -0.11 & 0.16 & $0.29 *$ & $0.26^{* *}$ & 0.15 & -0.06 \\
\hline FS & & & & & & & & & $0.96 * *$ & $0.50^{* * *}$ & $0.32^{*}$ & -0.11 & $0.44 * *$ & $0.21 * *$ \\
\hline AP & & & & & & & & & & $0.54 * *$ & $0.36^{*}$ & -0.09 & $0.55^{* *}$ & $0.22 * *$ \\
\hline AS & & & & & & & & & & & 0.04 & 0.07 & $0.39 * *$ & 0.03 \\
\hline ASC & & & & & & & & & & & & 0.04 & $0.39 * *$ & 0.01 \\
\hline CLC & & & & & & & & & & & & & 0.09 & 0.08 \\
\hline $\mathrm{CB}$ & & & & & & & & & & & & & & $0.33 * *$ \\
\hline
\end{tabular}

$\mathrm{MP}=$ milk production (liters/day); $\mathrm{LC}=$ number of lactating cows; $\mathrm{DC}=$ number of dry cows; $\mathrm{CC}=$ number of culled cows in the last twelve months; $\mathrm{HC} 1=$ number of heifer calves from one day to six months of age; $\mathrm{HC} 2=$ number of heifer calves from six to twelve months of age; HR = number of heifers raised on the farm for replacement in the last twelve months; $\mathrm{LL}=$ lactation length; $\mathrm{FS}=$ farm size; $\mathrm{AP}=$ area with pasture; $\mathrm{AS}=$ area for silage production; $\mathrm{ASC}=$ area with sugar-cane; $\mathrm{CLC}=$ amount of concentrate fed to lactating cows; $\mathrm{CB}=$ number of calves born in the last twelve months; $\mathrm{CD}=$ number of calves up to three months of age that died in the last twelve months; $* \mathrm{P}<0.05 ; * * \mathrm{P}<0.01$. 


\section{CONCLUSIONS}

The dairy-farming production system in Iporá and surroundings is based on strategies and techniques that result in a low level of productivity and dairy-specialization, which may reflect on the profitability and continuity of the dairy activity.

It is necessary that cooperatives, Rural Extension Agents, and Institutions of Education and Research work together with local farmers to contribute for the improvement of the dairy-farming production system through the adoption of technologies that will increase milk production and create new perspectives for rural development.

\section{ACKNOWLEDGMENTS}

The authors acknowledge the help afforded by AGRODEFESA, APROSANTA, COOMAFIR and the PROCRIA staff in approaching farmers for filling in questionnaires. This research was financially supported by CNPq (grant \# 94/2013, 487929/2013-6). Scholarship support for Kaique Moreira Dias and Marisa Marques Silva was from CNPq (grant \# 94/2013).

\section{REFERENCES}

BOTEGA, J. V. L.; BRAGA JÚNIOR, R. A.; LOPES, M. A.; RABELO, G. F. Diagnóstico da automação na produção leiteira. Ciência e Agrotecnologia, Lavras, v. 32, n. 2, p. 635-639, 2008.

CARVALHO, P. C. F.; ANGUINONI, I.; MORAES, A.; SOUZA, E. D.; SULC, R. M.; LANG, C. R.; FLORES, J. P. C.; LOPES, M. L. T.; SILVA, J. L. S.; CONTE, O.; WESP, C. L.; LEVIEN, R.; FONTANELI, R. S.; BAYER, C. Managing grazing animals to achieve nutrient cycling and soil improvement in no-till integrated systems. Nutrient Cycling in Agroecosystems, v. 88, p. 259-273, 2010.

CARVALHO, P. A.; SANCHEZ, L. M. B.; VELHO, J. P.; VIÉGAS, J.; JAURIS, G. C.; RODRIGUES, M. B. Características quantitativas, composição física tecidual e regional da carcaça de bezerros machos de origem leiteira ao nascimento, 50 e 110 dias de idade. Revista Brasileira de Zootecnia, Viçosa, v. 32, n. 6, p. 14761483, 2003.

CHAVES, N. P.; BEZERRA, D. C.; SOUSA, D. E.; SANTOS, H. P.; PEREIRA, H. M. Frequência e fatores associados à infecção pelo vírus da diarreia viral bovina em bovinos leiteiros não vacinados no Estado do Maranhão. Arquivos do Instituto Biológico, São Paulo, v. 79, n. 4, p. 495-502, 2012.

CHINElatTO NETO, A.; CASTRO, G. P. C.; LIMA, J. E. Uso de análise estatística multivariada para tipificação de produtores de leite de Minas Gerais. Organizações Rurais \& Agroindustriais, Lavras, v. 7, n. 1, p. 114$121,2005$.

COSTA, J. H. C.; HÖTZEL, M. J.; LONGO, C.; BALCÃO, L. F. A survey of management practices that influence production and welfare of dairy cattle on family farms in Southern Brazil. Journal of Dairy Science, Champaign, v. 96, n. 1, p. 307-317, 2013.

ELLIS, W. A. Bovine leptospirosis in the tropics: prevalence, pathogenesis and control. Preventive Veterinary Medicine, v. 2, n. 1-4, p. 411-421, 1984.

FAGUNDES, C. M.; FISHER, V.; SILVA, W. P.; CARBONERA, N.; ARAÚJO, M. R. Presença de Pseudomonas spp em função de diferentes etapas da ordenha com distintos manejos higiênicos e no leite refrigerado. Ciência Rural, Santa Maria, v. 36, n. 2, p. 568-572, 2006.

GUERREIRO, P. K.; MACHADO, M. R. F.; BRAGA, G. C.; GASPARINO, E.; FRANZENER, A. S. M. Qualidade microbiológica de leite em função de técnicas profiláticas no manejo de produção. Ciência e Agrotecnologia, Lavras, v. 29, n. 1, p. 216-222, 2005.

GUEDES, M. H. P.; GUIMARÃES, A. M.; ROCHA, C. M. B. M.; HIRSCH, C. Frequência de anticorpos antiNeospora caninum em vacas e fetos provenientes de municípios do sul de Minas Gerais. Revista Brasileira de Parasitologia Veterinária, Jaboticabal, v. 17, n. 4, p. 189-194, 2008.

INSTITUTO BRASILEIRO DE GEOGRAFIA E ESTATÍSTICA - IBGE. 2013. Pesquisa Pecuária Municipal.

Goiás/Amorinópolis/Diorama/Iporá/Israelância/Ivolância/Jau paci/Pecuária 2013. Online. Available at: http://www.cidades.ibge.gov.br/xtras/temas.php?lang=\& codmun $=520090 \&$ idtema $=121 \&$ search $=$ goias|amorinopo lis|pecuaria-2013 Accessed in January $27^{\text {th }} 2014$.

IBM Corp. IBM SPSS Statistics for Windows, version 21.0. Released 2012. Armonk, NY: IBM Corp.

JULIANO, R. S.; CHAVES, N. S. T.; SANTOS, C. A.; RAMOS, L. S.; SANTOS, H. Q.; MEIRELES, L. R.; GOTTSCHALK, S.; CORRÊA FILHO, R. A. C. Prevalência e aspectos epidemiológicos da leptospirose bovina em rebanho leiteiro na microrregião de Goiânia GO. Ciência Rural, Santa Maria, v. 30, n. 5, p. 857-862, 2000.

LEMOS, M. B.; CAMPOS, R. G. B.; BIASI, E.; SANTOS, F. Tecnologia, especialização regional e produtividade: um estudo da pecuária leiteira em Minas Gerais. Revista de Economia e Sociologia Rural, Brasília, v. 41, n. 3, p. 117-138, 2003.

LOPES, M. A.; DEMEU, F. A.; SANTOS, G.; CARDOSO, M. G. Impacto econômico do intervalo de partos em rebanhos bovinos leiteiros. Ciência e Agrotecnologia, Lavras, v. 33, edição especial, p. 1908-1914, 2009.

LOPES, P. F.; REIS, R. P.; YAMAGUCHI, L. C. T. Custos e escala de produção na pecuária leiteira: estudo nos principais estados produtores do Brasil. Revista de 
Economia e Sociologia Rural, Brasília, v. 41, n. 3, p. 567-590, 2007.

LOPES, M. A.; SANTOS, G., CARVALHO, F. M. Comparativo de indicadores econômicos da atividade leiteira de sistemas intensivos de produção de leite no Estado de Minas Gerais. Revista Ceres, Viçosa, v. 59, n. 4, p. 458-465, 2012.

MARTHA JÚNIOR, G. B.; ALVES, E.; CONTINI, E. Dimensão econômica de sistemas de integração lavourapecuária. Pesquisa Agropecuária Brasileira, Brasília, v. 46, n. 10, p. 1117-1126, 2011.

MILANI, A. P.; SOUZA, F. A. Granjas leiteiras na região de Ribeirão Preto - SP. Engenharia Agrícola, Jaboticabal, v. 30, n. 4, p. 742-752, 2010.

NEVES, J. P.; MIRANDA, K. L.; TORTORELLA, R. D. Progresso científico em reprodução na primeira década do século XXI. Revista Brasileira de Zootecnia, Viçosa, v. 39, suplemento especial, p. 414-421, 2010.

PORTELA, J. N.; VIEGAS, J.; NEUMANN, P. S.; LAURENTINO, L. D.; CASTAGNINO, G. Indicadores de desempenho zootécnico observados nas unidades de produção familiar associadas à Cooperativa dos Produtores de Leite de Santa Maria (COOPROL), RS. Ciência Rural, Santa Maria, v. 32, n. 3, p. 485-491, 2002.

REZENDE, P. L. P.; RESTLE, J.; FERNANDES, J. J. R.; PÁDUA, J. T.; FREITAS NETO, M. D.; PRADO, C. S.;
PEREIRA, M. L. R. Carcass and meat characteristics of crossbred steers submitted to different nutritional strategies at growing and finishing phases. Ciência Rural, Santa Maria, v. 42, n. 5, p. 875-881, 2012.

REZENDE, P. L. P.; RESTLE, J.; FERNANDES, J. J. R.; PÁDUA, J. T.; FREITAS NETO, M. D.; ROCHA, F. M. Desempenho e desenvolvimento corporal de bovinos leiteiros mestiços submetidos a níveis de suplementação em pastagem de Brachiaria brizantha. Ciência Rural, Santa Maria, v. 41, n. 8, p. 1453-1458, 2011.

ROCHA, M. A.; GOUVEIA, A. M. G.; LOBATO, Z. I. P.; LEITE, R. C. Pesquisa de anticorpos para IBR em amostragem de demanda no Estado de Minas Gerais, 1990-1999. Arquivo Brasileiro de Medicina Veterinária e Zootecnia, Belo Horizonte, v. 53, n. 6, p. 645-647, 2001.

SALTON, J. C.; MERCANTE, F. M.; TOMAZI, M.; ZANATTA, J. A.; CONCENÇO, G.; SILVA, W. M.; RETORE, M. Integrated crop-livestock system in Brazil: toward a sustainable production system. Agriculture, Ecosystems and Environment, v. 190, p. 70-79, 2014.

YAMAMURA, A. A. M.; MÜLLER, E. E.; FREIRE, R. L.; FREITAS, J. C.; PRETTO-GIORDANO, L. G.; TOLEDO, R. S.; RIBEIRO, M. G. Fatores de risco associado à mastite bovina causada por Prototheca zopfii. Ciência Rural, Santa Maria, v. 38, n. 3, p. 755760, 2008. 